Article

\title{
Competence-Based Management Research in the Web of Science and Scopus Databases: Scientific Production, Collaboration, and Impact
}

\author{
Vítor Vasata Macchi Silva ${ }^{1, *(\mathbb{D}}$, José Luis Duarte Ribeiro ${ }^{1}{ }^{\circledR}$, Gonzalo Rubén Alvarez ${ }^{2}$ and $^{(}$ \\ Sonia Elisa Caregnato 2 (D) \\ 1 Industrial Engineering Graduate Program, Federal University of Rio Grande do Sul, Osvaldo Aranha Av., 99, \\ 5th Floor, Porto Alegre 90.035-190, RS, Brazil; ribeiro@producao.ufrgs.br \\ 2 Communication and Information Graduate Program, Federal University of Rio Grande do Sul, \\ Ramiro Barcelos St., 2705, 214, Porto Alegre 90.035-007, RS, Brazil; gonzalorubenalvarez@gmail.com (G.R.A.); \\ sonia.caregnato@ufrgs.br (S.E.C.) \\ * Correspondence: vasata@hotmail.com; Tel.: +55-51-33083720
}

Received: 15 July 2019; Accepted: 20 September 2019; Published: 24 September 2019

check for updates

\begin{abstract}
This paper presents a bibliometric study, which seeks to characterize papers that address competence-based management and that are indexed in the Web of Science and Scopus databases in terms of scientific production, collaboration, and impact. All the papers published in journals or in conference proceedings that contained the terms "competenc* management" or "compentenc ${ }^{*}$ based management" in their titles, abstracts, or keywords were analyzed. The results show that computational sciences, human resources management, strategic management, and industrial relations and labor correspond to the macro-categories that characterize competence-based management. This paper also indicates that collaborations between authors do not establish strong co-authorship networks. It also shows that the most cited papers were published in journals of different areas. It concludes that studies conducted in the area of competence-based management can be developed in a more assertive way if they take into consideration the context of the current state of research in this area.
\end{abstract}

Keywords: competence-based management; scientific communication; bibliometrics; bibliometric indicators

\section{Introduction}

Competence-based management is the way companies manage organizational competencies of groups and individuals [1]. As a method of management, its primary objective is to define the competencies that are needed for the organization to obtain and continuously sustain success according to organizational goals. Therefore, competence-based management is considered important for the achievement of the organization's goals, to improve business processes, and customer services [2,3]. It is also believed that, for an organization, adopting competence-based management means to assume a strategic posture aligned with the established organizational goals, whatever they might be. This aspect allows us to infer that this management method can be used in different contexts and that there are benefits that can be obtained from the use of the explicit process of strategic formulation.

In the field of studies about scientific production it is perceived that the growth of the literature does not depend on the area being investigated, but it seems to be a consequence of the intensity of research and the amount of researchers that work in a specific area [4]. Bibliometrics, in this context, can support the study of scientific production. It consists of a set of statistical methods for studying the structure and process of scholarly communication [5], including characteristics of documents' use and creation, such as the amount of papers in a determined field, primary authors, citations received, 
among other aspects. Therefore, bibliometric analysis is thought to contribute to the elucidation of what are the main ideas, schools of thought, and the relations that exist between them in a given field of research [6].

In the context of competence-based management it is assumed that a bibliometric study can contribute to a better understanding of this area, by presenting its structures and analyzing its development [7]. Furthermore, Prévot et al. [7] highlights that, from bibliometric studies, the researchers in the field can position their investigations and identify new areas of research for practical and theoretical investigations. In addition, these authors emphasize that, for those who are less familiarized with the topic, such studies can contribute to the identification of the main challenges in the field and their developments.

Considering the aspects presented above, the general aim of this paper is to characterize papers that address competence-based management, which are indexed in the databases Web of Science and Scopus in terms of scientific production, collaboration, and impact. These databases were chosen for being the main ones used in metrics analysis, and also, for allowing the evaluation of indexed papers in terms of productivity and citations received [8,9]. Therefore, the specific objectives are to: (i) identify the profile of the research addressing competence-based management indexed in the Web of Science and Scopus databases, concerning document type, year of publication, language, and the journal or proceedings in which the paper was published; (ii) indicate the most productive country, institution, and authors in the field of competence-based management; (iii) indicate the main issues being researched in the field of competence-based management; (iv) identify the existing collaborations in these indexed papers in the selected databases; and (v) characterize the impact of the papers that address competence-based management indexed in the Web of Science and Scopus databases.

\subsection{Competence-Based Management}

Organizations are under sustained pressure to improve the efficiency and effectiveness of the human resources function. To do so, approaches for managing employees are being rethought [10]. According to Guillaume, Houé and Grabot [11], an efficient management of the operational performance of human resources requires being able to allocate the right person to a task or role within a business process. In this context, competence-based management has arisen as an alternative management model, since it translates strategic organizational goals into essential organizational (personnel) requirements necessary for any particular function [12]. This approach to human resource management is based on identifying, defining, and measuring individual differences in terms of specific work-related constructs, especially the abilities that are critical to successful job performance [13]. Therefore, competence management should address all processes involved in the production, implementation, and development of specific competencies [14]. Palacios-Marqués et al. [15] also highlight that, when successfully implemented, competence-based management can measure and improve employees' competences and value such competences to develop employees' careers.

A competence-based approach has one key feature that fundamentally differentiates it from traditional methods of analyzing human capital requirements of organizations [16]. This is the effective desired characteristics that are described in broader terms - competencies-that themselves represent aggregates of individual knowledge, skills, and personality characteristics [16]. To Özçelik and Ferman [17], by focusing on competence applications, organizations are using competencies to integrate selection, training, performance appraisal, career development and compensation. In performance appraisal, e.g., competencies are used to identify factors relevant to performance in the job and compare how a job is done to the results achieved [17].

Nevertheless, the adoption of a competence-based approach to human resource management raises a number of questions concerning how competencies can be elicited, described, and assessed, and how to develop managerial systems to map competence profiles, evaluate them, and manage their development [18]. In this context, Leme Fleury and Correa Fleury [19] point out that, in order for competence-based management to reach its potential, the development of individual competencies 
must be in line with the organizational strategy. However, this activity is not a simple task, since the value of individual competencies differs according to the characteristics of the organization in which the workers act [19]. Belkadi et al. [14], complementary, emphasized that an important task of competence management is the characterization that consists of formalizing the competence and determining its key components as well as the situation features that link a particular competence with the actor's activity. According to Colomo-Palacios et al. [20] and Sanchez [21], the identification of competences that match job requirements is a major issue in human resource development.

For Berio and Harzallah [22], four macro-processes are included in competence-based management: competence identification, competence assessment, competence acquisition, and competence usage. The identification of competencies, in this scenario, should be responsible for highlighting when and how to identify the competencies required to perform tasks, strategies, and missions. Competence assessment, in turn, should be responsible for defining when and how to evaluate the individual competencies acquired and/or define when and how an organization can assess whether its employees have acquired specific competencies. The acquisition of competencies, in a complementary manner, should be responsible for deciding when to acquire competencies, and finally, competence usage should be responsible for using the information and knowledge acquired, and based on that, identify gaps between the required competencies and the existing competencies in an organization [22].

In the context of competence-based management and knowledge management, Flöck and Mekhilef [23] suggest that the detailed analysis of scientific production in this area helps to demonstrate that these management models have become a topic of interest in most fields of sciences and techniques. The evidence for such interest, according to these authors, is the existence of a great number of actors (universities, consultants, industries), the abundance of publications, the different contact networks, and the increasing offer of specialized training. Moreover, Flöck and Mekhilef [23] establish that the great variety of viewpoints and interpretations that permeate these management models invite an understanding of the attributed meanings of these models.

\subsection{Bibliometrics and Bibliometric Indicators}

Bibliometrics correspond to a technique that seeks to describe the characteristics of documents' use and development [24]. The potential of bibliometric studies is related to their capacity of organizing sociological patterns of explicit recognition among individual documents and of analyzing the changes operated in scientific fields or domains over time $[25,26]$. Furthermore, the indicators based on a bibliometric methodology can promote the comprehension of the researchers' position in the context of international research in terms of influence and specialization, and also, the understanding of scientific patterns and processes of knowledge dissemination [27]. Moreover, as highlighted by García-Lillo et al. [28], the fascination to know the "state-of-the-art" often grows among scholars and investigators as a "discipline" advances and reaches a certain level of development. This occurs because these researchers seek to comprehend, through analysis of research carried out by a great amount of authors on a given topic, which contributions have had a higher influence on its evolution or have managed to capture the greatest attention of the researchers [28].

Regarding the uses of bibliometrics, Hjørland [26] and Köseoğlu et al. [29] highlight that this has become popular as an instrument of viewing scientific areas by the analysis of citations, co-citations, and also through the development of bibliometric maps. Van Raan [27] emphasizes that, to monitor the development of science, the technique of bibliometric mapping, also known as bibliometric cartography, provides an instrument for the development of a context where cognitive structures of a scientific field of research can be identified.

Van Eck and Waltman [30] suggest that bibliographic maps can be based on distance or, in some cases, on graphs. In maps based on distance, small distances represent stronger links between the items-an aspect that facilitates the process of identifying clusters but makes the process of item labeling more difficult, as some points might overlap with others [30]. On the other hand, on maps based on graphs, the distance between the nodes does not represent the relationship between the items, 
since the strength of the relations is represented through lines, which are thicker according to the intensity of the identified relation [30]. This aspect, according to Van Eck and Waltman [30], decreases the possibility of overlapping the labels, but it makes it difficult to identify clusters and to analyze the intensity of the relations that already exist.

Spinak [24], when discussing metric studies, also stresses the relevance of productionindicators, which measure productivity aspects; and the citation indicators, which measure the amount and the impact of the relations between current scientific publications. Okubo [31], however, classifies the bibliometric indicators as indicators of scientific and technological activity (production indicators) and relational indicators (collaboration indicators), which measure the links and the interactions between the actors that play a role in sciences and technology.

\subsection{Bibliometric Studies in Competence-Based Management}

Each scientific discipline stems from a collection of relevant studies that start to be acknowledged as the basis for future investigations. In the field of human resources management investigations, Fernandez-Alles and Ramos-Rodríguez [32] show interest in analyzing the most influential studies and authors in the area in order to identify how the area has developed and what the current research topics are. Fernandez-Alles and Ramos-Rodríguez [32] also claim that there is a paradoxical contrast between the weakness of studies with a quantitative approach in human resources management and the strength of these investigations in other fields of management, where several studies have already used this technique.

From the first books dedicated to competence-based management, dated from the 1990s, to the more recent publications, the area of competence-based management has experienced significant development [7]. In order to prove this and analyze how the area has developed through time, Prévot et al. [7] have deemed it sufficient to characterize the scientific production about this theme published in the journal Research in Competence-Based Management, and also in a series of books published after several editions of the international conference on competence-based management. Based on these materials, the authors have identified three issues of the journal and 12 books that cover a total of 185 papers written by 213 authors published between the years of 1994 and 2005.

The results of the study conducted by Prévot et al. [7] reveals that $77 \%$ of the authors published only one paper about the topic and that nine authors during the period analyzed were responsible for $30 \%$ of all the papers produced in the field of competence-based management. In addition, this study has identified that the authors' affiliations were distributed in 21 different countries, while the first five countries (United States, Netherlands, Belgium, United Kingdom, and France) represented 57\% of the authors. Taking into consideration the authors' institution of origin, Prévot et al. [7] identified that there is not one institution leading the investigations in competence-based management, and also, that there is not a group of authors coming from a single institution writing about this topic.

Finally, Prévot et al. [7] highlighted that papers about competence-based management tend to be organized around references directly related to the topic. This, according to the authors, shows that this field of research has achieved a level of maturity and that it has defined its differences in relation to other fields of research.

\section{Materials and Methods}

Traditionally, bibliometric analyses were conducted based on information about publications and citations provided by Web of Science (WoS) $[8,33$ ]. Nevertheless, the launching of the Scopus database by Elsevier, in 2004, has created an alternative capable of competing with the monopoly established by WoS [33]. Nowadays, WoS and Scopus are the most frequently used citation databases to evaluate journals in terms of productivity and citations received [9].

This study grouped the results of the bibliographic search about competence-based management obtained in these two databases. This is justified, as the addition of the citations obtained in the Scopus 
database to the results obtained in the WoS database can significantly alter aspects like the ranking of the most productive authors [34].

\subsection{Search Strategies Used for the Data Collection}

Bibliometric studies rely on the establishment of an adequate search strategy in order to obtain the records regarding the publication of relevant investigations [35]. Hence, a search strategy was developed that considers the terminological variations for the terms "competence management" and "competence based-management", using the omission represented by the character "*" (see Table 1). This way, the results encompass papers that use the terms "competency management", "competencies management", as well as "competency based-management".

The search strategy was implemented in title, abstract, and keywords fields, as a way to filter only papers about this topic published in journals and in conference proceedings, from the beginning of the indexation in the two databases to the end of 2015. This is justified, as the omission of conference proceedings in bibliometric studies might result in a breach in the analysis, especially when single entities, such as authors and institutions, are analyzed [36]. Moreover, as is pointed out by Hofer et al. [37], the addition of papers published in conference proceedings allows the researcher to obtain a detailed and holistic perspective of the research that is being developed.

Table 1 presents the databases in which the terms were searched, the type of research that was conducted in each database and, also, the fields and search phrase used.

Table 1. Strategies for the identification of papers about competence-based management.

\begin{tabular}{cccccc}
\hline Databases & $\begin{array}{c}\text { Types of } \\
\text { Research }\end{array}$ & Search Fields & Search Phrase & $\begin{array}{c}\text { Stipulated } \\
\text { Period }\end{array}$ & $\begin{array}{c}\text { Type of } \\
\text { Document }\end{array}$ \\
\hline $\begin{array}{c}\text { Web of } \\
\text { Science }\end{array}$ & Basic search & $\begin{array}{c}\text { TS = Topic (title, summary, } \\
\text { author's keywords and } \\
\text { keyword plus) }\end{array}$ & $\begin{array}{c}\text { "competenc* management" } \\
\text { OR "competenc* based } \\
\text { management" }\end{array}$ & $\begin{array}{c}\text { Article OR } \\
\text { Conference } \\
\text { Paper }\end{array}$ \\
\hline Scopus & $\begin{array}{c}\text { Document } \\
\text { search }\end{array}$ & $\begin{array}{c}\text { TITLE-ABS-KEY (Article } \\
\text { title, Abstract, Keywords) }\end{array}$ & $\begin{array}{c}\text { "competenc* management" } \\
\text { OR "competenc* based } \\
\text { management" }\end{array}$ & $\begin{array}{c}\text { All years to } \\
2015\end{array}$ & $\begin{array}{c}\text { Article OR } \\
\text { Conference } \\
\text { Paper }\end{array}$ \\
\hline
\end{tabular}

\subsection{Bibliometric Indicators}

In order to characterize the production, collaboration, and impact of the scientific production in competence-based management indexed in the WoS and Scopus databases, several analyses were conducted, as listed in Table 2. The table presents, also, the relations between the steps of analysis and the objectives of this paper, furthermore, it also presents the types of indicators identified.

Table 2. Specific objectives, databases fields, and analysis conducted.

\begin{tabular}{|c|c|c|c|c|c|}
\hline Specific Objectives & $\begin{array}{l}\text { Necessary } \\
\text { Information }\end{array}$ & $\begin{array}{l}\text { Fields } \\
\text { WoS }\end{array}$ & $\begin{array}{l}\text { Fields } \\
\text { Scopus }\end{array}$ & Conducted Analysis & $\begin{array}{l}\text { Types of } \\
\text { Indicators }\end{array}$ \\
\hline \multirow{5}{*}{$\begin{array}{l}\text { To identify the profile of the } \\
\text { research addressing } \\
\text { competence-based } \\
\text { management and that are } \\
\text { indexed in the Web of Science } \\
\text { and Scopus databases, in } \\
\text { relation to the document type, } \\
\text { year of publication, language } \\
\text { and journal or conference } \\
\text { proceedings in which the } \\
\text { studies were published. }\end{array}$} & $\begin{array}{l}\text { Document } \\
\text { type }\end{array}$ & DT & M3 & $\begin{array}{l}\text { Amount of papers } \\
\text { per document type }\end{array}$ & \multirow{5}{*}{$\begin{array}{l}\text { Production } \\
\text { indicators }\end{array}$} \\
\hline & & & & $\begin{array}{l}\text { Amount of papers } \\
\text { per document type }\end{array}$ & \\
\hline & $\begin{array}{l}\text { Publication } \\
\text { Year }\end{array}$ & PY & PY & $\begin{array}{l}\text { Amount of paper per } \\
\text { publication year }\end{array}$ & \\
\hline & $\begin{array}{l}\text { Languages of } \\
\text { the Journals }\end{array}$ & LA & LA & $\begin{array}{l}\text { Amount of papers } \\
\text { per language }\end{array}$ & \\
\hline & $\begin{array}{l}\text { Journals or } \\
\text { conferences }\end{array}$ & $\mathrm{SO}$ & $\mathrm{T} 2$ & $\begin{array}{l}\text { Amount of papers } \\
\text { per source type }\end{array}$ & \\
\hline
\end{tabular}


Table 2. Cont.

\begin{tabular}{|c|c|c|c|c|c|}
\hline Specific Objectives & $\begin{array}{c}\text { Necessary } \\
\text { Information }\end{array}$ & $\begin{array}{l}\text { Fields } \\
\text { WoS }\end{array}$ & $\begin{array}{l}\text { Fields } \\
\text { Scopus }\end{array}$ & Conducted Analysis & $\begin{array}{l}\text { Types of } \\
\text { Indicators }\end{array}$ \\
\hline \multirow{3}{*}{$\begin{array}{l}\text { To indicate the countries, the } \\
\text { institutions, and the authors } \\
\text { that are most productive in } \\
\text { competence-based } \\
\text { management. }\end{array}$} & \multirow[t]{2}{*}{ Addresses } & \multirow[t]{2}{*}{$\mathrm{C} 1$} & \multirow[t]{2}{*}{$\mathrm{AD}$} & $\begin{array}{l}\text { Amount of papers } \\
\text { per country }\end{array}$ & \\
\hline & & & & $\begin{array}{l}\text { Amount of papers } \\
\text { per institution }\end{array}$ & \\
\hline & Authors & $\mathrm{AU}$ & $\mathrm{AU}$ & $\begin{array}{l}\text { Amount of papers } \\
\text { per author }\end{array}$ & \\
\hline $\begin{array}{l}\text { To indicate the main topics in } \\
\text { the scope of } \\
\text { competence-based } \\
\text { management. }\end{array}$ & Keywords & $\mathrm{DE}+\mathrm{ID}$ & KW & $\begin{array}{l}\text { Most used keywords } \\
\text { to represent the } \\
\text { papers }\end{array}$ & \\
\hline \multirow{3}{*}{$\begin{array}{l}\text { To identify collaborations in } \\
\text { the papers indexed in the } \\
\text { databases selected to the } \\
\text { analysis. }\end{array}$} & \multirow[t]{2}{*}{ Addresses } & \multirow[t]{2}{*}{$\mathrm{C} 1$} & \multirow[t]{2}{*}{$\mathrm{AD}$} & $\begin{array}{c}\text { Collaboration } \\
\text { between countries }\end{array}$ & \multirow{3}{*}{$\begin{array}{l}\text { Indicators of } \\
\text { collaboration }\end{array}$} \\
\hline & & & & $\begin{array}{c}\text { Collaboration } \\
\text { between institutions }\end{array}$ & \\
\hline & Authors & AU & $\mathrm{AU}$ & $\begin{array}{l}\text { Collaborations } \\
\text { between authors }\end{array}$ & \\
\hline \multirow{2}{*}{$\begin{array}{l}\text { To characterize the impact of } \\
\text { the papers that address the } \\
\text { competence-based } \\
\text { management and that are } \\
\text { indexed in WoS and in } \\
\text { Scopus. }\end{array}$} & \multirow[t]{2}{*}{ Citations } & \multirow[t]{2}{*}{$\mathrm{TC}$} & \multirow[t]{2}{*}{$\mathrm{TC}$} & $\begin{array}{c}\text { Amount of citations } \\
\text { per paper }\end{array}$ & \multirow[b]{2}{*}{$\begin{array}{l}\text { Impact } \\
\text { indicators }\end{array}$} \\
\hline & & & & $\begin{array}{l}\text { Characterization of } \\
\text { the most cited papers }\end{array}$ & \\
\hline
\end{tabular}

\subsection{Characterization of the Paper Methodology}

In order to achieve all the objectives proposed for this study, different procedures were executed. The first step was to collect the information of the papers indexed in the WoS and Scopus databases that are related to competence-based management. This procedure was conducted on 19 August 2016. Table 3 presents the amount of papers retrieved and the search strategies employed in each database.

Table 3. Strategies of search conducted, and the results obtained in Web of Science and Scopus databases.

\begin{tabular}{|c|c|c|}
\hline Databases & Search Strategies Executed & Total \\
\hline Web of Science & $\begin{array}{l}(T S=(" c o m p e t e n c * \text { management" OR "competenc* based management")) } \\
\text { AND DOCUMENT TYPES: (Article OR Proceedings Paper }) \\
\text { Indexes = SCI-EXPANDED, SSCI, A\&HCI, CPCI-S, CPCI-SSH, ESCI } \\
\text { Timespan }=1945-2015\end{array}$ & 264 \\
\hline Scopus & $\begin{array}{l}\text { TITLE-ABS-KEY ("competenc* management" OR “competenc* based } \\
\text { management") AND PUBYEAR < } 2016 \text { AND (LIMIT-TO (DOCTYPE, } \\
\text { "cp") OR LIMIT-TO (DOCTYPE, “ar")) }\end{array}$ & 522 \\
\hline
\end{tabular}

Table 3 shows that the amount of papers that address the topic of competence-based management retrieved in Scopus corresponds to almost double the amount of papers retrieved at WoS. This result is aligned to the Bartol et al. [38] claim, who highlighted that the Scopus database contains more results in the total amount of documents, when compared to the WoS database, due to the fact that it has a greater coverage of journals indexed.

After the data collection, the documents that contained expressions such as "[...] competence, management $[\ldots]$ ". " [...] competence. Management [...]" and "[...] competence: management [...]" in their titles, summaries, or keywords were removed. By doing this, the analysis of papers that do not represent the exact expressions of research ("competenc* management" or "competenc* based 
management") was avoided. Later, duplicate papers were identified. Table 4 presents the results obtained after this preliminary data treatment.

Table 4. Amount of records retrieved at the databases Web of Science and Scopus.

\begin{tabular}{ccccc}
\hline Stage & $\begin{array}{c}\text { WoS } \\
\text { Only }\end{array}$ & $\begin{array}{c}\text { Scopus } \\
\text { Only }\end{array}$ & $\begin{array}{c}\text { Both } \\
\text { Databases }\end{array}$ & Total \\
\hline $\begin{array}{c}\text { After the initial search } \\
\text { After the preliminary cleaning of the documents }\end{array}$ & 264 & 522 & - & - \\
After identifying the duplicates & 62 & 509 & - & - \\
\hline Percentage over total & $10.9 \%$ & 511 & 198 & 571 \\
\hline
\end{tabular}

The corpus of the study was composed of 571 papers. These papers address competence-based management and are indexed in the WoS and Scopus databases. The amount of papers available at Scopus, in relation to the total (509 in 571), indicates that this database indexes almost $90 \%$ of the papers that address competence-based management and that are available in one of these databases.

After identifying the papers that composed the corpus of research, the data was further cleaned. This was necessary since the data collected at the databases usually contain mistakes in the name of the authors, journal titles, and reference lists [39], which would make it difficult for the mapping of the scientific production directly related to the bibliographic sources. In addition to these mistakes, the format of the bibliographic register differed in the two databases used, which had to be taken into account.

The cleaning of the data collected in the databases was conducted in two stages. In the first one, the fields that identified the information provided by the databases were standardized. Thus, the records obtained in WoS which used "DT" to represent the field document type were replaced by "M3", which is used by Scopus to represent the same information. In the second stage of data treatment, the manual standardization of the information related to journals, conferences, countries, institutions, and authors was conducted. This standardization was necessary as some of the journal and conference titles were not included exactly in the same way in the WoS and Scopus databases [40].

The data analysis, conducted after the cleaning of the records, was divided into indicators of production, collaboration, and impact. In order to generate these indicators, the software BibExcel and Excel were used. BibExcel was chosen for the data analysis since it makes possible the reading of records collected in the WoS and Scopus databases. Furthermore, it has the great advantage of its flexibility of integration with other tools of bibliometric analysis. For the elaboration of bibliometric maps, the software UCINET was used, which is one of the most important software for network analysis [41].

Finally, the results of data analyses were interpreted. This interpretation was used to identify the publication trends about the topic of competence-based management. As a result, this stage presented an overview of the scientific production in competence-based management indexed in the investigated databases, and it has fulfilled the general goals established for this paper.

\section{Results and Discussion}

\subsection{Production Indicators}

The first aspect analyzed was the document typology from the files retrieved in the WoS and Scopus databases. This analysis showed that 295 (51.66\%) from the 571 records retrieved were published in Proceedings and 276 (48.34\%) were published in Journals. This result shows that Conferences are important channels for sharing investigations on competence-based management. This result also reinforces Glänzel et al.'s [42] argument that the publication in conference proceedings is of great relevance for the studies in engineering and applied sciences, because these fields are not appropriately covered in journals of the area. 
Figure 1 presents the amount of documents retrieved per year.

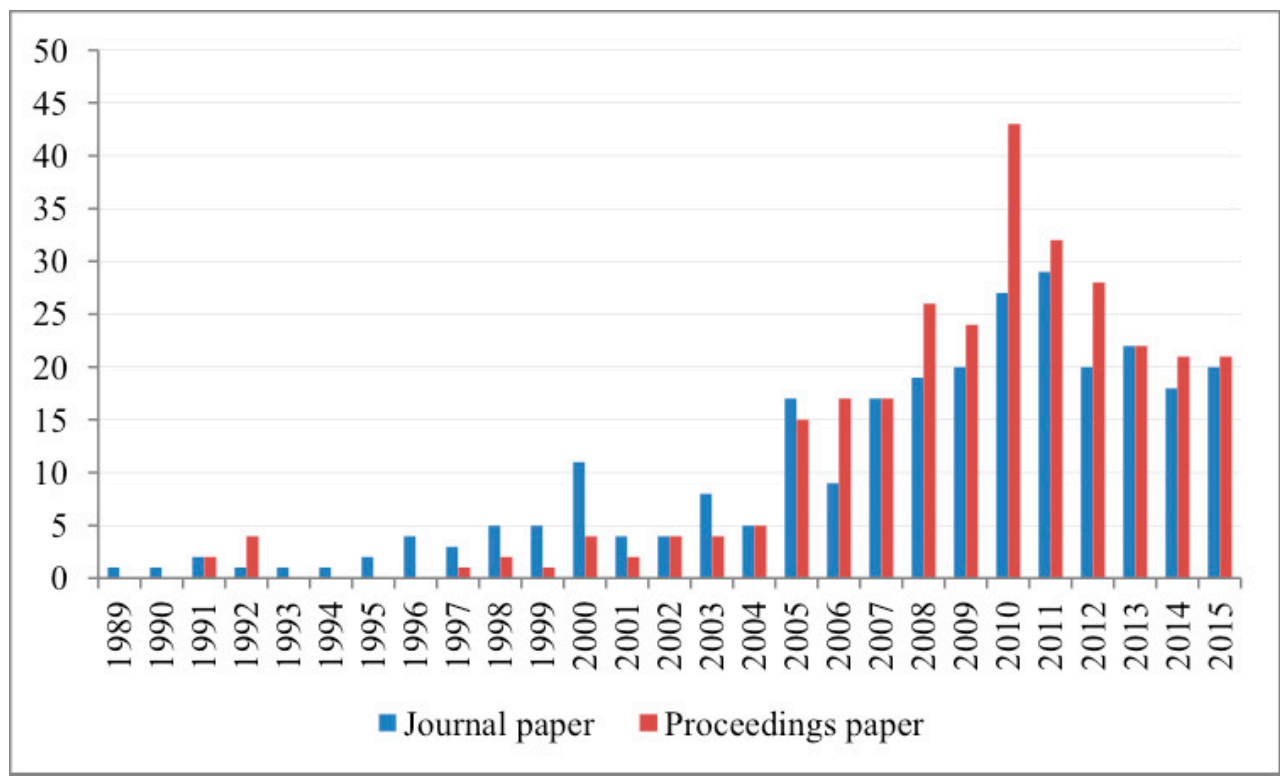

Figure 1. Occurrence of document types per year of publication.

Most of the occurrences of papers that address competence-based management were published between the years of 2010 and 2011. It is worth noticing that, in Figure 1, competencies have become a recurrent theme in the literature to a significant extent since the year of 2005-until 2004, only 87 papers, $15.24 \%$ of the total, had already been published. To a certain extent, this increase in the amount of papers published in the year of 2005 is due to the publication of issue 83 of the journal Public Administration, as it was dedicated to the topics of "competencies" and competence-based management. The oldest paper on this subject corresponds to a paper by Albanese [43], published in the Journal of Management Development in 1989, entitled Competency-based Management Education. This paper highlights the premises of education in competence-based management and presents its emergence in the educational context. Regarding the languages of these studies, 519 of them, or $90.89 \%$ of the papers retrieved were published in English.

Table 5 presents the publisher, the country of origin, and the impact factor (IF) of the 14 journals that have published the most articles about the theme studied here.

Table 5. Journals with the highest number of publications related to competence-based management.

\begin{tabular}{|c|c|c|c|c|c|c|c|}
\hline Rank & Journal & Occurrences & $\%$ & $\sum \%$ & Publisher & Country & IF (2018) \\
\hline 1 & $\begin{array}{c}\text { Research in } \\
\text { Competence-Based } \\
\text { Management }\end{array}$ & 9 & 3.26 & 3.26 & $\begin{array}{l}\text { Emerald Group } \\
\text { Publishing Ltd. }\end{array}$ & England & N/A \\
\hline 2 & $\begin{array}{l}\text { Journal of Universal } \\
\text { Computer Science }\end{array}$ & 7 & 2.54 & 5.80 & Springer Verlag & Austria & 0.910 \\
\hline 3 & Personnel Review & 5 & 1.81 & 7.61 & $\begin{array}{l}\text { Emerald Group } \\
\text { Publishing Ltd. }\end{array}$ & England & 1.362 \\
\hline 4 & Computers in Industry & 5 & 1.81 & 9.42 & Elsevier BV & Netherlands & 4.769 \\
\hline 5 & $\begin{array}{l}\text { International Journal of } \\
\text { Technology Management }\end{array}$ & 5 & 1.81 & 11.23 & $\begin{array}{l}\text { Inderscience } \\
\text { Publishers }\end{array}$ & Switzerland & 1.160 \\
\hline 6 & Public Administration & 4 & 1.45 & 12.68 & Wiley-Blackwell & England & 2.600 \\
\hline 7 & $\begin{array}{l}\text { Knowledge Management } \\
\text { and E-Learning }\end{array}$ & 4 & 1.45 & 14.13 & $\begin{array}{l}\text { University of } \\
\text { Hong Kong }\end{array}$ & China & N/A \\
\hline 8 & $\begin{array}{l}\text { IEEE Transactions on } \\
\text { Engineering Management }\end{array}$ & 3 & 1.09 & 15.22 & $\begin{array}{l}\text { Institute of } \\
\text { Electrical and } \\
\text { Electronics } \\
\text { Engineers }\end{array}$ & $\begin{array}{l}\text { United } \\
\text { States }\end{array}$ & 1.867 \\
\hline
\end{tabular}


Table 5. Cont.

\begin{tabular}{|c|c|c|c|c|c|c|c|}
\hline Rank & Journal & Occurrences & $\%$ & $\sum \%$ & Publisher & Country & IF (2018) \\
\hline 9 & Management Decision & 3 & 1.09 & 16.30 & $\begin{array}{l}\text { Emerald Group } \\
\text { Publishing Ltd. }\end{array}$ & England & 1.963 \\
\hline 10 & $\begin{array}{l}\text { International Journal of } \\
\text { Production Economics }\end{array}$ & 3 & 1.09 & 17.39 & Elsevier BV & Netherlands & 4.998 \\
\hline 11 & Management Learning & 3 & 1.09 & 18.48 & $\begin{array}{c}\text { SAGE } \\
\text { Publications }\end{array}$ & England & 1.935 \\
\hline 12 & $\begin{array}{l}\text { International Journal of } \\
\text { Project Management }\end{array}$ & 3 & 1.09 & 19.57 & Elsevier BV & England & 4.694 \\
\hline 13 & $\begin{array}{c}\text { International Journal of } \\
\text { Public Sector } \\
\text { Management }\end{array}$ & 3 & 1.09 & 20.65 & $\begin{array}{l}\text { Emerald Group } \\
\text { Publishing Ltd. }\end{array}$ & England & N/A \\
\hline 14 & $\begin{array}{c}\text { Journal of Management } \\
\text { Development }\end{array}$ & 3 & 1.09 & 21.74 & $\begin{array}{l}\text { Emerald Group } \\
\text { Publishing Ltd. }\end{array}$ & England & N/A \\
\hline & Other & 216 & 78.26 & - & - & - & - \\
\hline & Total & 276 & 100 & - & - & - & - \\
\hline
\end{tabular}

A total of 276 papers have been published in 200 distinct journals, while only $21.74 \%$ of this total has been published in journals that accepted three or more papers about competence-based management. The Research in Competence-Based Management is the journal that has published the most papers about this topic, which seems natural, considering that its main concern is competence-based management followed by some peripheral subjects such as entrepreneurship, innovation, and organization diversification. This indicates that the Prévot et al. [7] study, which analyzed all the papers published in this journal between the years of 1994 and 2005, has taken into consideration competence-based management, and also themes that are related to it.

Table 6 presents the title of the conferences that have published the most papers addressing competence-based management.

Table 6. Conferences that most accepted papers addressing competence-based management.

\begin{tabular}{|c|c|c|c|}
\hline Rank & Event & Occurrences & $\%$ \\
\hline 1 & European Conference on Knowledge Management, ECKM & 13 & 4.41 \\
\hline 2 & International Conference on Rail Human Factors & 8 & 2.71 \\
\hline 3 & $\begin{array}{c}\text { IFAC Symposium on Information Control Problems in } \\
\text { Manufacturing, INCOM }\end{array}$ & 6 & 2.03 \\
\hline 4 & $\begin{array}{l}\text { IFIP WG 5.5 Working Conference on Virtual Enterprises, } \\
\text { PRO-VE }\end{array}$ & 6 & 2.03 \\
\hline 5 & $\begin{array}{c}\text { Portland International Conference on Management of } \\
\text { Engineering and Technology, PICMET }\end{array}$ & 5 & 1.69 \\
\hline 6 & $\begin{array}{c}\text { IEEE International Conference on Advanced Learning } \\
\text { Technologies, ICALT }\end{array}$ & 5 & 1.69 \\
\hline 7 & Conference on Professional Knowledge Management & 5 & 1.69 \\
\hline \multirow[t]{3}{*}{8} & IET International Conference on System Safety & 5 & 1.69 \\
\hline & Other & 242 & 82.03 \\
\hline & Total & 295 & 100 \\
\hline
\end{tabular}

The European conference on knowledge management (ECKM) was the main conference for the publication of papers related to this area. This performance showcases the direct relation between competence-based management and knowledge management, as the former is part of the latter. This occurs because competence-based management seeks to plan, capture, develop, and assess, at the different levels of the organization, the necessary competences to the accomplishment of its goals. Knowledge management, in turn, acts in a complementary way, identifying the knowledge that people have and providing the means for the development, transfer, and use of this knowledge. 
The analysis of which countries are most productive in competence-based management took into account the institutional address of the authors, as is shown in Table 7. To analyze such information, it is important to highlight that we count when multiples authors from the same country appeared as authors in a paper only once.

Table 7. Occurrences of most productive countries in the scope of competence-based management.

\begin{tabular}{cccc}
\hline Rank & Country & Occurrences & $\%$ \\
\hline 1 & Germany & 63 & 9.91 \\
2 & France & 63 & 9.91 \\
3 & United Kingdom & 56 & 8.81 \\
4 & United States & 38 & 5.97 \\
5 & Italy & 36 & 5.66 \\
6 & Brazil & 35 & 5.50 \\
7 & Finland & 30 & 4.72 \\
8 & Netherlands & 23 & 3.62 \\
9 & Sweden & 21 & 3.30 \\
10 & Spain & 20 & 3.14 \\
\hline \multicolumn{5}{c}{ Other } & 251 & 39.47 \\
\hline & Total & 636 & 100 \\
\hline
\end{tabular}

Germany, France, United Kingdom, and the United States are the countries that have published the most articles about this theme. In a similar way, Prévot et al. [7] have identified the United States, United Kingdom, and France as three of the five most productive countries in the scope of competence-based management and its related fields. Nevertheless, while Prévot et al.'s [7] research has identified 21 different countries associated with this topic of research, this study has identified 65 countries. Based on this dispersion, it is possible to infer that the scientific production in competence-based management is expanding, mainly in countries that do not have research tradition on this area.

Table 8 presents the results of the analysis of institutions associated with these papers.

Table 8. Occurrences of most productive institutions in competence-based management.

\begin{tabular}{ccccc}
\hline Rank & Institution & Country & Occurrences & $\%$ \\
\hline 1 & Ecole Centrale Paris & France & 9 & 1.07 \\
2 & University of Salerno & Italy & 9 & 1.07 \\
3 & University of São Paulo & Brazil & 9 & 1.07 \\
4 & West Pomeranian University of Technology & Poland & 9 & 1.07 \\
5 & University of Amsterdam & Netherlands & 8 & 0.95 \\
6 & Lappeenranta University of Technology & Finland & 7 & 0.83 \\
7 & University of Nantes & France & 7 & 0.83 \\
8 & Vienna University of Technology & Austria & 7 & 0.83 \\
\hline \multicolumn{7}{r}{ Others } & & 777 & 92.28 \\
\hline & Total & & 842 & 100 \\
\hline
\end{tabular}

The results indicate that there is no single institution leading the research on this topic, similarly to what Prévot et al. [7] had found. Nevertheless, Europe is the continent where the institutions that publish the most about competence-based management are based, as 7 out of the 8 most productive institutions are located in this continent.

In order to identify the most productive authors in competence-based management, it was necessary, initially, to manually standardize the data, as the information related to authorship was presented in distinct forms in the two databases. At WoS, for instance, Marinita Schumacher is presented as "Schumacher M", while at Scopus the author is indicated as "Schumacher, M.". Table 9 presents the results obtained. 
Table 9. Most productive authors in the field of competence-based management.

\begin{tabular}{|c|c|c|c|c|c|c|}
\hline Rank & Author & Occurrences & Country & Institution & Department & h-Index \\
\hline 1 & Cardinal, J.S.-L. & 8 & France & Ecole Centrale Paris & $\begin{array}{l}\text { Laboratoire Genie } \\
\text { Industriel }\end{array}$ & 6 \\
\hline 2 & Orciuoli, F. & 8 & Italy & Universita di Salerno & $\begin{array}{l}\text { Department of } \\
\text { Management and } \\
\text { Innovation Systems }\end{array}$ & 16 \\
\hline 3 & Rózewski, P. & 8 & Poland & $\begin{array}{l}\text { West Pomeranian } \\
\text { University of } \\
\text { Technology }\end{array}$ & $\begin{array}{l}\text { Faculty of Computer } \\
\text { Science }\end{array}$ & 8 \\
\hline 4 & Afsarmanesh, $\mathrm{H}$. & 7 & Netherlands & $\begin{array}{l}\text { University of } \\
\text { Amsterdam }\end{array}$ & Faculty of Science & 25 \\
\hline 5 & Gaeta, M. & 6 & Italy & Universita di Salerno & $\begin{array}{l}\text { Dipartimento di } \\
\text { Ingegneria } \\
\text { dell'Informazione }\end{array}$ & 21 \\
\hline 6 & Harzallah, M. & 6 & France & Université de Nantes & $\begin{array}{c}\text { Laboratoire } \\
\text { d'Informatique de } \\
\text { Nantes-Atlantique }\end{array}$ & 9 \\
\hline 7 & Malachowski, B. & 6 & Poland & $\begin{array}{c}\text { West Pomeranian } \\
\text { University of } \\
\text { Technology }\end{array}$ & $\begin{array}{l}\text { Faculty of Computer } \\
\text { Science }\end{array}$ & 5 \\
\hline 8 & Schumacher, M. & 6 & France & Ecole Centrale Paris & $\begin{array}{l}\text { Department of } \\
\text { Industrial } \\
\text { Engineering }\end{array}$ & 4 \\
\hline & Other & 1513 & - & - & - & \\
\hline & Total & 1568 & - & - & - & \\
\hline
\end{tabular}

The eight most productive authors work in European institutions. They are connected to universities and research institutes related to different specialties, and each of them have published six or more papers. On the other hand, $82.82 \%$ of the authors have published only one paper. Table 9 also shows that all the most productive authors have h-index 4 or higher (according Scopus, at September, 2019). This metric measures the researcher productivity and also the citation impact of their publications. So, if the researcher has h-index 4 , this means that the scientist has published at least four papers that have each been cited at least four times.

The identification of the subjects that are most addressed in the papers that compose this research corpus was conducted using the keywords that the authors have attributed to the papers, and also the keywords that the databases have attributed to the papers. Table 10 presents the occurrences of frequent keywords and the percentage of its presence in relation to the total amount of papers $(n=571)$.

Table 10. Most frequently used terms to describe the papers.

\begin{tabular}{|c|c|c|c|c|c|c|c|c|}
\hline Rank & Term & 1989-1995 & 1996-2000 & 2001-2005 & 2006-2010 & 2011-2015 & $\sum$ Occurrences & $\%$ \\
\hline 1 & $\begin{array}{l}\text { Competence } \\
\text { management }\end{array}$ & 1 & 4 & 23 & 92 & 125 & 245 & 42.91 \\
\hline 2 & $\begin{array}{l}\text { Knowledge } \\
\text { management }\end{array}$ & 0 & 2 & 9 & 48 & 44 & 103 & 18.04 \\
\hline 3 & Management & 4 & 1 & 3 & 32 & 32 & 72 & 12.61 \\
\hline 4 & $\begin{array}{l}\text { Competency } \\
\text { management }\end{array}$ & 0 & 1 & 6 & 27 & 27 & 61 & 10.68 \\
\hline 5 & Ontology & 0 & 0 & 2 & 29 & 24 & 55 & 9.63 \\
\hline 6 & $\begin{array}{l}\text { Human resource } \\
\text { management }\end{array}$ & 0 & 1 & 2 & 12 & 31 & 46 & 8.06 \\
\hline 7 & $\begin{array}{l}\text { Personnel } \\
\text { training }\end{array}$ & 0 & 0 & 2 & 16 & 20 & 38 & 6.65 \\
\hline 8 & $\begin{array}{c}\text { Project } \\
\text { management }\end{array}$ & 0 & 1 & 8 & 9 & 20 & 38 & 6.65 \\
\hline 9 & $\begin{array}{c}\text { Societies and } \\
\text { institutions }\end{array}$ & 0 & 0 & 10 & 14 & 13 & 37 & 6.48 \\
\hline 10 & Competences & 0 & 3 & 5 & 21 & 7 & 36 & 6.30 \\
\hline 11 & Semantic web & 0 & 0 & 2 & 16 & 16 & 34 & 5.95 \\
\hline 12 & $\begin{array}{c}\text { Industrial } \\
\text { management }\end{array}$ & 2 & 3 & 11 & 14 & 2 & 32 & 5.60 \\
\hline
\end{tabular}


Table 10. Cont.

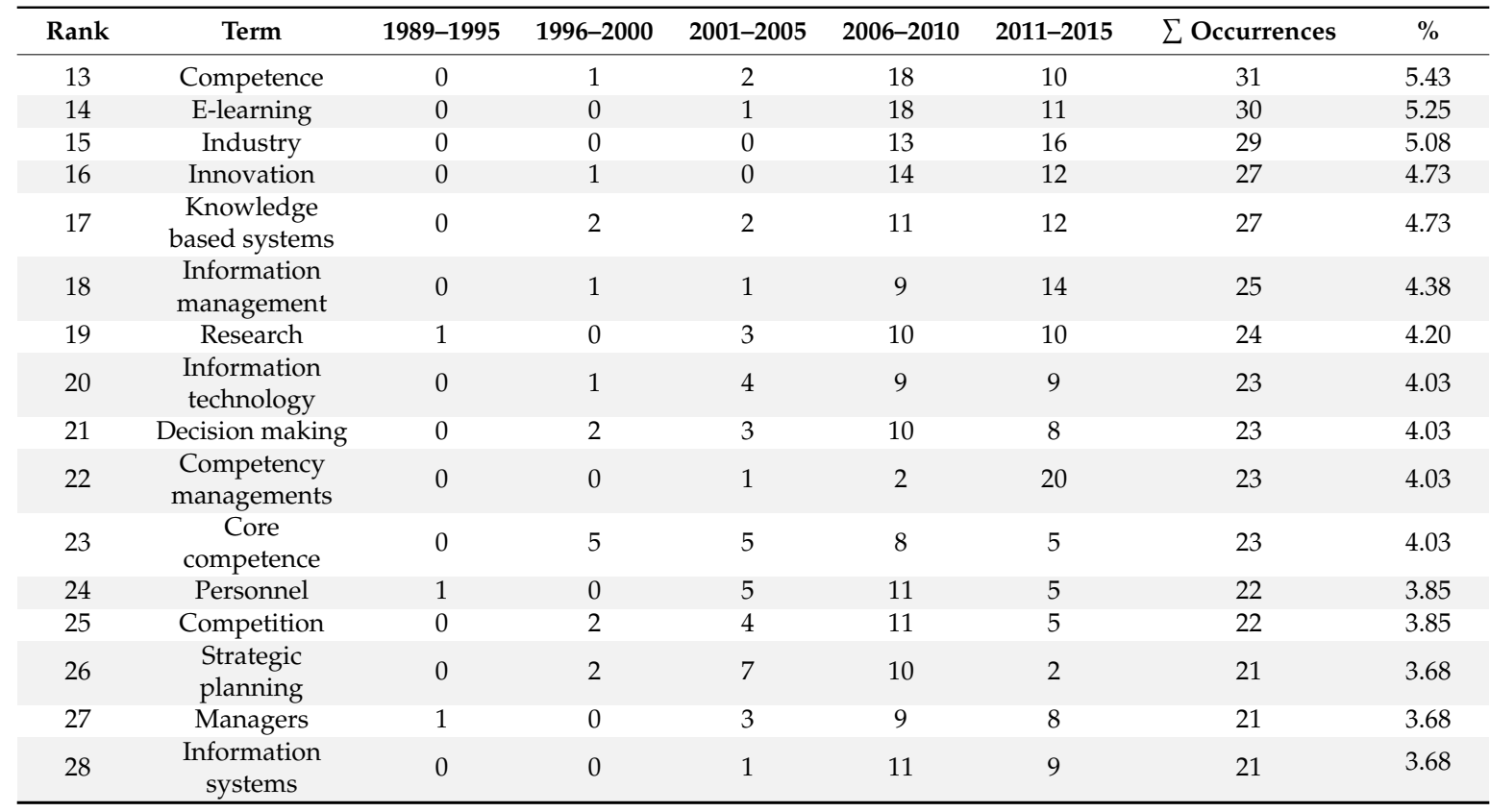

Competence management is the most often-used term to describe the papers, followed by knowledge management, which reinforces the existing bond between competence-based management and knowledge management, as previously discussed. Management and competency management also appear in the top positions, and they highlight the managerial character of competence-based management, as well as one of its terminological variations. About this variations, Moghabghab et al. [44] highlights that "competence" can be understand as a capability for consistently integrating the required knowledge, skill, and judgments, while "competency" can be understood as a component of knowledge, skill, and/or judgment demonstrated by an individual. Table 10 also highlights that the search phrase "competenc* management" was most frequently associated with computer sciences and informational systems terms, such as ontology, semantic web, e-learning, and knowledge-based systems, after 2006. This reinforces the connection that was established between these research topics, and also the technology evolution that enabled the utilization of these applications.

Based on the bibliometric mapping of the keywords that were used 20 times or more in the papers represented in the corpus, a network of 28 terms was generated. In this network, the strength of the relationship between the words is presented by the thickness of the lines. Figure 2 presents the network developed.

Competence management is the term that has a stronger relation with the other terms in the diagram and, together with the terms knowledge management and management, compose the core of this research area. Complementarily, the relations that competence-based management establish with human resource management, personnel training, project management, industry, and ontology can be highlighted, as these associations emphasize different contexts of use of this management method.

In addition to the core of competence-based management, composed by the terms knowledge management, competence management, and management, it was also possible to identify four other macro-categories by the grouping of the other keywords. Those are: computer sciences and informational systems; human resources management; strategic management, which is highly related to the core; and industrial relations and labor. 


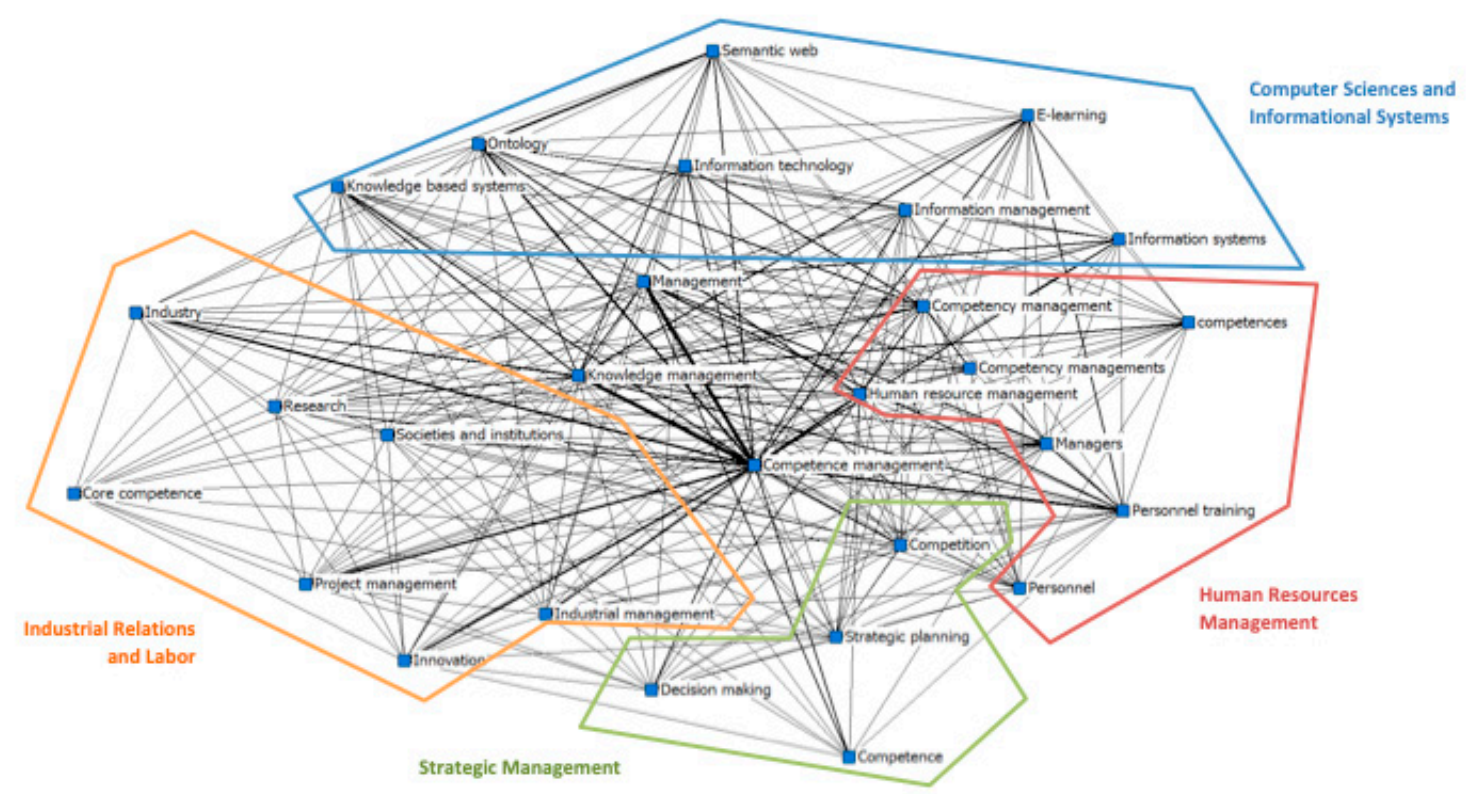

Figure 2. Macro-categories that characterize competence-based management.

\subsection{Collaboration Indicators}

Collaboration between countries was identified based on the professional addresses of the authors of each paper in international co-authorship. Table 11 presents the results observed in 541 papers, as the address information was not available in thirty papers that composed the corpus.

Table 11. Occurrences and amount of countries associated to each paper.

\begin{tabular}{ccc}
\hline Amount of Countries & Occurrences & $\mathbf{\%}$ \\
\hline 1 & 461 & 85.21 \\
2 & 67 & 12.38 \\
3 & 11 & 2.03 \\
4 & 2 & 0.37 \\
\hline Total & 541 & 100 \\
\hline
\end{tabular}

It is possible to notice that the most papers $(85.21 \%)$ were written by authors established in one country, which indicates that international collaboration is not a widely spread practice. Figure 3 represents the interaction between the countries of the authors who have conducted studies in collaboration.

Figure 3 shows that the United States and France are the countries that have the most papers in collaboration with other countries-24 papers were elaborated in collaboration with at least one American or French author. On the other hand, the most productive countries (Germany and France) did not establish international partnerships that address competence-based management.

The collaboration between institutions has also been identified based on the professional addresses available on the papers.

Table 12 shows that $39.56 \%$ of the papers had interinstitutional collaboration, which makes this type of collaboration more widespread than international collaborations. The collaborations between institutions that have published one or more papers addressing competence-based management is shown in Figure 4, which presents the bibliographic map generated based on interinstitutional collaborations. 


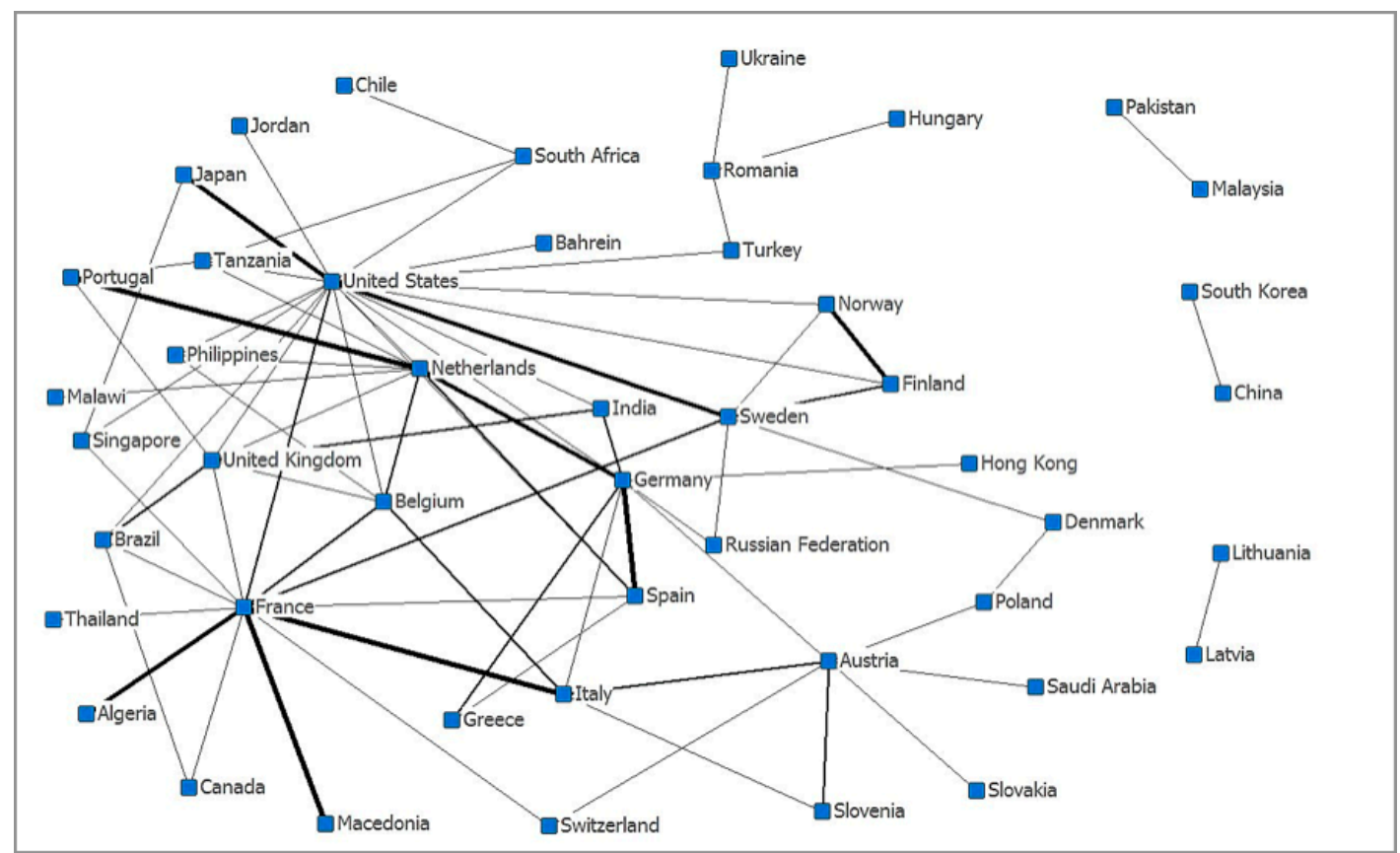

Figure 3. International collaboration in studies related to the field of competence-based management.

Table 12. Amount of institutions associated in the papers.

\begin{tabular}{ccc}
\hline Amount of Institutions & Occurrences & $\mathbf{\%}$ \\
\hline 1 & 327 & 60.44 \\
2 & 153 & 28.28 \\
3 & 48 & 8.87 \\
4 & 7 & 1.29 \\
5 & 3 & 0.55 \\
6 & 0 & 0.00 \\
7 & 2 & 0.37 \\
8 & 1 & 0.18 \\
\hline Total & 541 & 100 \\
\hline
\end{tabular}

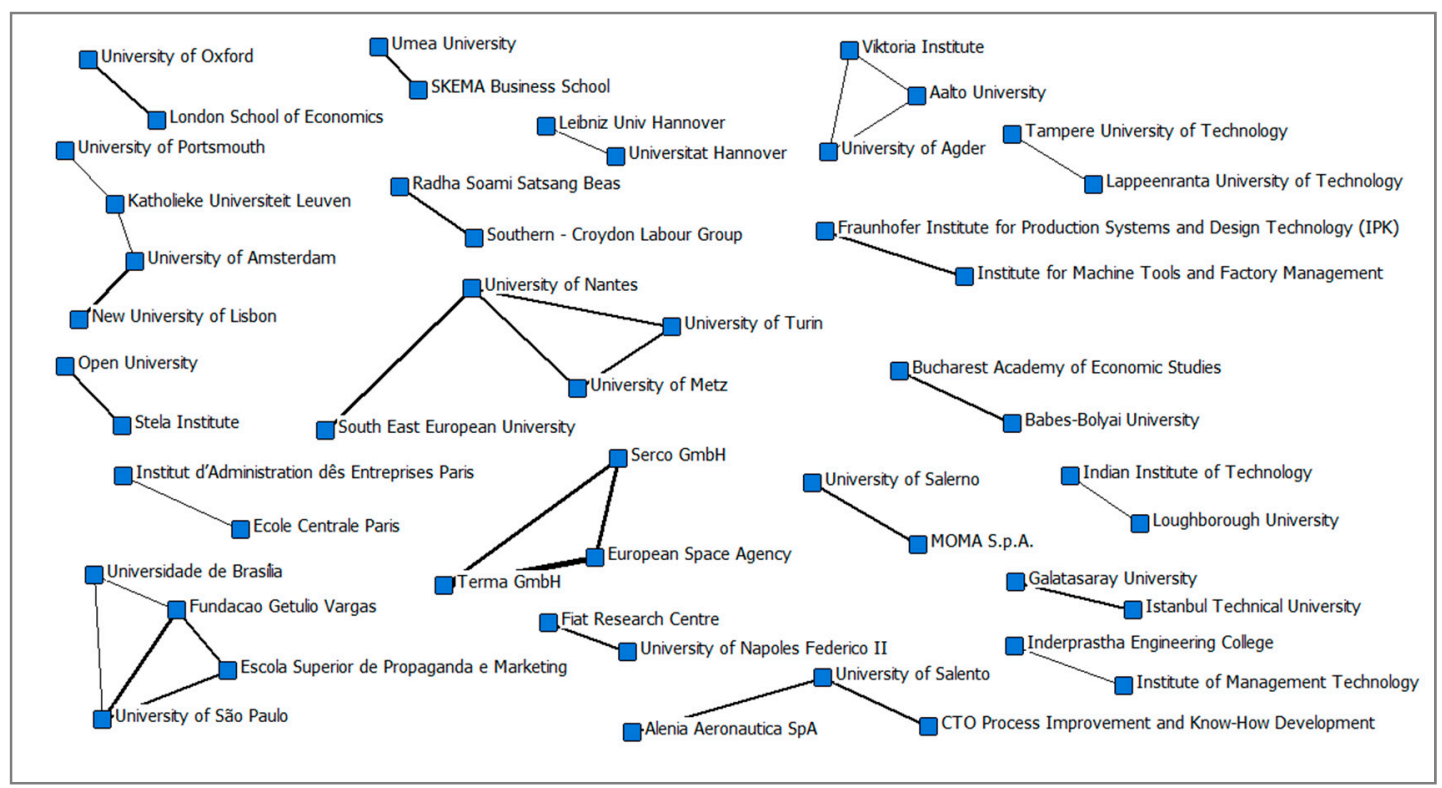

Figure 4. Interinstitutional collaboration in studies related to competence-based management. 
Collaborations between institutions do not configure a dense collaboration network. This characteristic can be justified by the fact that there is not a leading research institution in this area-an aspect that decentralizes the studies and minimizes the possibilities of experiences' exchanges. It is important to note, in Figure 4, the high incidence of papers in collaboration with the European space agency (ESA) and the companies Terma GmbH (Darmstadt, Germany) and Serco GmbH (Darmstadt, Germany), which are specialized in aerospace products and services management, respectively, which reinforces these collaborations.

Table 13 presents the amount of authors per paper, except for six registers, in which the authorship information was not available.

Table 13. Amount of authors associated per paper.

\begin{tabular}{ccc}
\hline Amount of Authors & Occurrence & $\mathbf{\%}$ \\
\hline 1 & 120 & 21.24 \\
2 & 197 & 34.87 \\
3 & 141 & 24.96 \\
4 & 57 & 10.09 \\
5 & 31 & 5.49 \\
6 & 10 & 1.77 \\
7 & 7 & 1.24 \\
11 & 1 & 0.18 \\
128 & 1 & 0.18 \\
\hline Total & 565 & 100 \\
\hline
\end{tabular}

The majority of papers $(78.76 \%)$ contain two or more authors, which supports what is argued by Glänzel and Schubert [45], that there is a tendency in all areas for publications to have co-authorship. From these papers, $34.87 \%$ were elaborated by two authors. Besides, it stands out that the mean of authors per article is 2.55 (with a standard deviation of 1.34), not taking into consideration the study that had 128 members of a life sciences committee as authors.

In order to identify these networks of co-authorship, the collaborations made between those who have published three or more papers about the same subject of research were identified. Figure 5 represents the bibliometric mapping made based on this analysis.

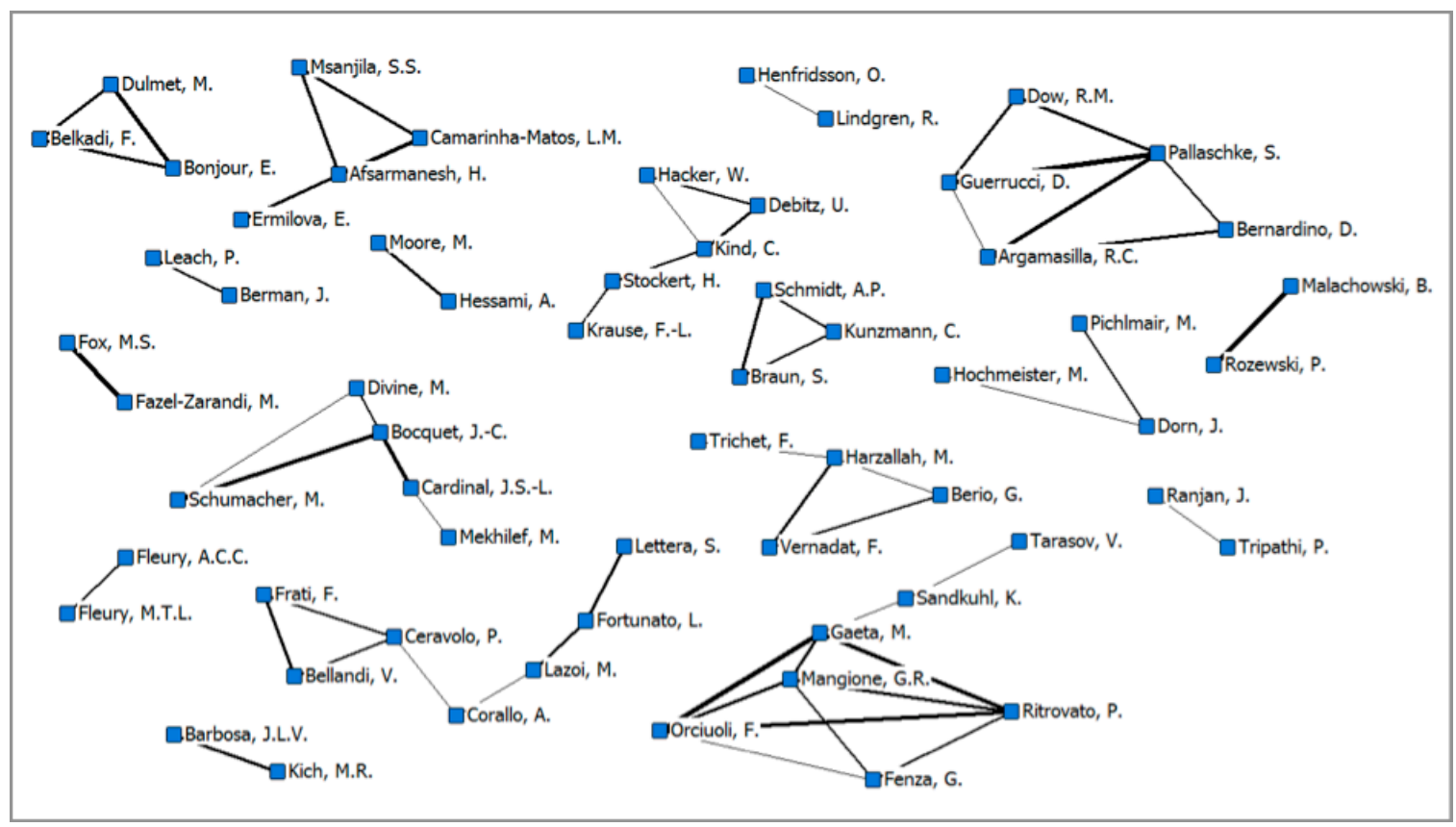

Figure 5. Collaboration between authors in studies that address competence-based management. 
The graph in Figure 5 shows that the network between the authors of studies that address competence-based management does not represent a dense network of collaboration. The strongest connections established are between the authors Gaeta, Ritrovato, Fenza, Orciuoli, and Mangione, related to the University of Salerno, and Dow, Pallaschke, Bernardino, Argamasilla, and Guerrucci, related to ESA. These networks contribute for these institutions to be seen as the ones that have the greatest numbers of authors interested in the issue of competence-based management. In addition to these aspects, it is possible to note the high incidence of collaborations between Rozewski and Malachowski, from the West Pomeranian university of technology (Poland). Besides this, the graph presents all top eight most productive authors cited in Table 9.

\subsection{Impact Indicators}

For the analysis of citations, the information provided in the fields times cited (TC) in the databases was used. Table 14 presents the 10 most cited papers and their main characteristics.

Table 14. Most cited papers that address competence-based management.

\begin{tabular}{|c|c|c|c|}
\hline Citations & Paper Titles & Authors & Sources Titles \\
\hline 325 & Action Design Research & Sein et al. [46] & $\begin{array}{l}\text { MIS Quarterly: Management } \\
\text { Information Systems }\end{array}$ \\
\hline 279 & $\begin{array}{l}\text { Managing radical innovation: An } \\
\text { overview of emergent strategy issues }\end{array}$ & $\begin{array}{c}\text { McDermott and } \\
\text { O'Connor [47] }\end{array}$ & $\begin{array}{l}\text { Journal of Product Innovation } \\
\text { Management }\end{array}$ \\
\hline 143 & $\begin{array}{l}\text { Design principles for competence } \\
\text { management systems: A synthesis of an } \\
\text { action research study }\end{array}$ & Lindgren et al. [48] & $\begin{array}{l}\text { MIS Quarterly: Management } \\
\text { Information Systems }\end{array}$ \\
\hline 102 & $\begin{array}{l}\text { Critical success factors from IT } \\
\text { outsourcing theories: An empirical study }\end{array}$ & $\begin{array}{l}\text { Gottschalk and } \\
\text { Solli-Sæther [49] }\end{array}$ & $\begin{array}{l}\text { Industrial Management and } \\
\text { Data Systems }\end{array}$ \\
\hline 98 & $\begin{array}{l}\text { Understanding competence-based } \\
\text { management-Identifying and managing } \\
\text { five modes of competence }\end{array}$ & Sanchez [21] & Journal of Business Research \\
\hline 76 & $\begin{array}{l}\text { The contribution of technology selection } \\
\text { to core competencies }\end{array}$ & $\begin{array}{l}\text { Torkkeli and } \\
\text { Tuominen [50] }\end{array}$ & $\begin{array}{l}\text { International Journal of } \\
\text { Production Economics }\end{array}$ \\
\hline 55 & $\begin{array}{l}\text { IT-based competency modeling and } \\
\text { management: From theory to practice in } \\
\text { enterprise engineering and operations }\end{array}$ & $\begin{array}{l}\text { Harzallah and } \\
\text { Vernadat [51] }\end{array}$ & Computers in Industry \\
\hline 41 & $\begin{array}{l}\text { Knowledge sharing: Agile methods vs. } \\
\text { Tayloristic methods }\end{array}$ & Chau et al. [52] & $\begin{array}{l}\text { IEEE International Workshops } \\
\text { on Enabling Technologies: } \\
\text { Infrastructure for Collaborative } \\
\text { Enterprises, WETICE }\end{array}$ \\
\hline 40 & $\begin{array}{l}\text { Modeling and management of profiles } \\
\text { and competencies in VBEs }\end{array}$ & $\begin{array}{c}\text { Ermilova and } \\
\text { Afsarmanesh [53] }\end{array}$ & $\begin{array}{l}\text { Journal of Intelligent } \\
\text { Manufacturing }\end{array}$ \\
\hline 1606 & Other & - & - \\
\hline 2765 & Total & - & - \\
\hline
\end{tabular}

The paper entitled "action design research" is the most cited paper among those that compose the corpus of this study. In this paper, Sein et al. [46] presented the action design research (ADR), research methodology that integrates information technology and organizational contexts, exemplifying its application in the Volvo automobile manufacturer. As a benefit of using ADR, Sein et al. [46] mentioned knowledge creation, which occurs from the development of information technology that takes into consideration the existent organizational contexts.

Considering Table 14, only two authors, Afsarmanesh (Amsterdam University) and Harzallah (Nantes University), are in the group of authors considered the most productive in the area (according to Table 9). Therefore, author productivity is not, necessarily, related to the amount of citations that a paper receives. Considering the other authors cited, these have in common the fact that they developed investigations related to information technology and for the modeling of competence-based management in virtual environments. 
Considering the journals that were published the most cited papers, it is possible to observe that they are distributed in areas, such as Information Systems Science (MIS Quarterly and Computers in Industry), Production and Operations Management (Journal of Product Innovation, Industrial Management and Data Systems, International Journal of Production Economics and Journal of Intelligent Manufacturing), and Business (Journal of Business Research)—an aspect that reinforces the interdisciplinary character of competence-based management.

Finally, the papers that compose the corpus of this research have received a total of 2877 citations-performance that indicates an average of 5.04 citations per work (standard deviation of 21.24). Furthermore, it is possible to perceive that 301 papers $(52.71 \%$ of the total) had not been cited by the literature in the field until the data collection.

\subsection{Interpretation of the Analysis}

The results of this study show the general characteristics of papers published in journals and conference proceedings indexed in the databases WoS and Scopus. Table 15 highlights the types of indicators used, the analysis conducted, the main results found, and the preliminary conclusions of this study.

Table 15. Characteristics of the papers that address competence-based management.

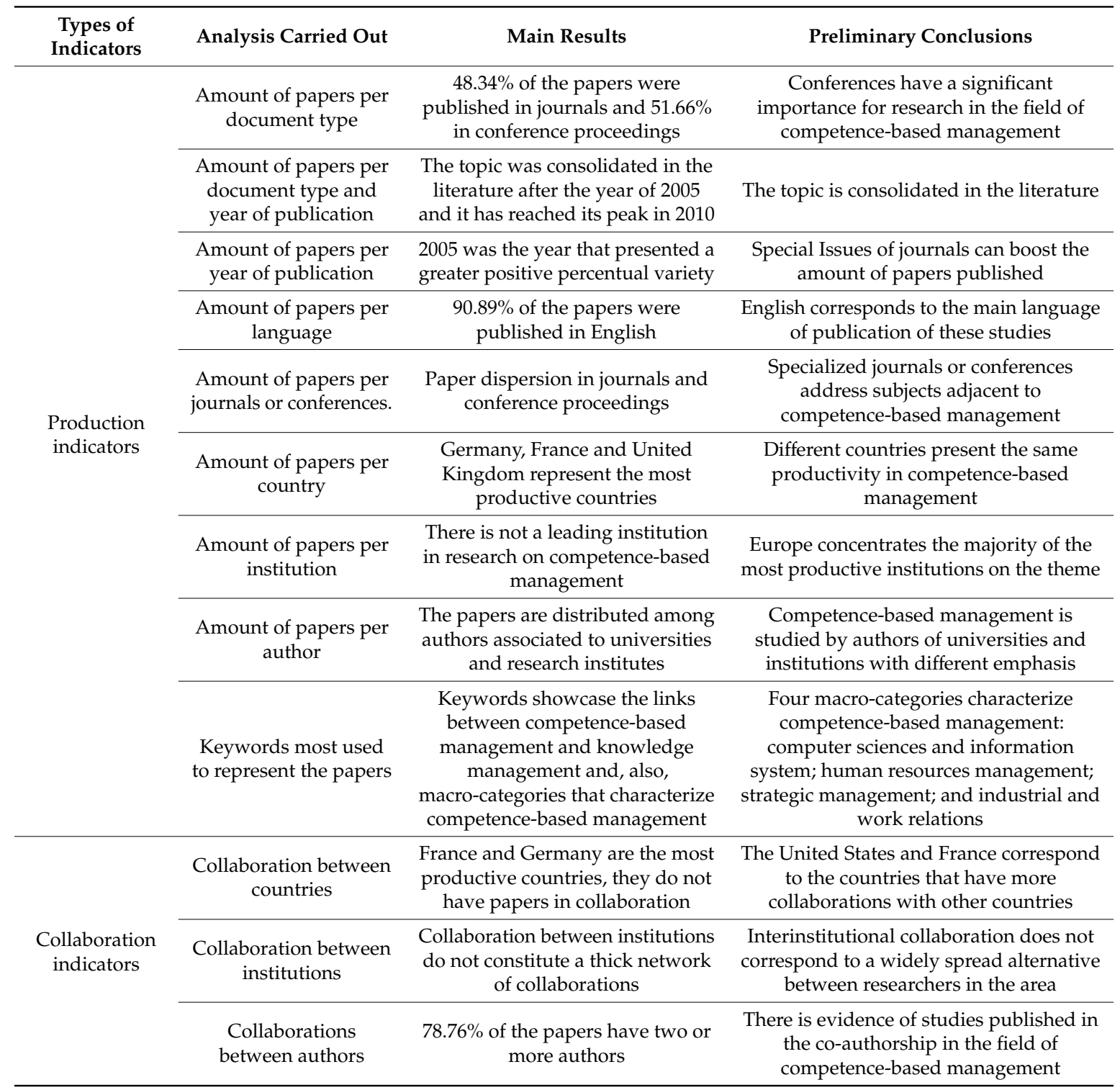


Table 15. Cont.

\begin{tabular}{cccc}
\hline $\begin{array}{c}\text { Types of } \\
\text { Indicators }\end{array}$ & Analysis Carried Out & Main Results & Preliminary Conclusions \\
\hline Impact & Amount of citations \\
per paper & $\begin{array}{c}\text { Only two authors of the most } \\
\text { cited authors are among the most } \\
\text { productive ones }\end{array}$ & $\begin{array}{c}\text { The most productive authors are not } \\
\text { necessarily the most cited ones }\end{array}$ \\
\cline { 2 - 4 } & $\begin{array}{c}\text { Characterization of the } \\
\text { most cited papers }\end{array}$ & $\begin{array}{c}\text { The most cited papers are spread } \\
\text { in specialized journals in } \\
\text { different areas }\end{array}$ & $\begin{array}{c}\text { Information Systems Science, Production } \\
\text { and Operations Management, and } \\
\text { Business correspond to the concentration } \\
\text { fields of Journals in which the most cited } \\
\text { papers were published }\end{array}$ \\
\hline
\end{tabular}

Table 15 shows that conferences are an important communication channel for researchers in the field of competence-based management. This aspect was highlighted from the identification that more than $50 \%$ of the works that deal with competence-based management, and are indexed in the WoS and Scopus databases, were published in conferences proceedings. In addition, it was also identified that competence-based management corresponds to a consolidated topic in the literature. This aspect was evidenced by Figure 1, which showed that the apex of publications on the topic was reached in 2010.

In addition, it is noteworthy that the drop in the number of publications on competence-based management in recent years may indicate that authors interested in the subject may have migrated to adjacent themes. The identification of the number of papers published per year also showed that 2005 corresponded to the year with the highest positive percentage variation in relation to the previous year. The analysis of this year's publications, in turn, showed the presence of a special volume of the Public Administration journal, which concentrated different publications on competence-based management. This aspect contributed to the conclusion that special journal editions can leverage the publication rate of works and contribute to the consolidation of different topics in the literature.

The analysis of the number of works per language, in turn, contributed to the confirmation that English corresponds to the main language of scientific communication. This aspect was reinforced by the fact that over $90 \%$ of the works were published in this language. Regarding the works published in journals or conferences, it was highlighted that there is a low concentration of papers in them. This feature reinforces that competence-based management is a topic that is presented alongside adjacent subject in journals and conferences in the area.

Regarding the analysis of the amount of papers published by countries and institutions, it is noteworthy that there is no country or institution that leads the research in the area of competence-based management. The performance achieved by Germany, France, and the United Kingdom, and by universities and institutions linked to these countries, in turn, has contributed to Europe being seen as the continent that concentrates most of the most productive institutions on the subject.

The analysis of the amount of papers published by author, complementarily, pointed out that there is not one author that stands out in the scope of research in competence-based management. The subsequent analysis, which observed the affiliation of such authors, evidenced that competence-based management corresponds to a topic that is the subject of study in universities and research institutions. This characteristic contributes to the inference that cooperation agreements can be signed between universities and organizations from different sectors so that experiences can be shared.

The analysis of the most used keywords to represent the papers reinforced, in turn, the existing link between competence-based management and knowledge management. This aspect was observed, as these terms were the most used to represent the works. In addition, such analysis also highlighted the macro-categories that characterize competence-based management. They are: Computer Science and Information Systems; Human Resource Management; Strategic Management; and Industrial Relations and Labor. These categories were those that encompassed the 28 most used terms to represent the works.

Collaboration indicators have shown that cross-country collaborations do not correspond to a widespread practice in the area of competence-based management. In this context, it was emphasized that France and Germany, the most productive countries in the subject, did not present any collaborative 
work among themselves. This aspect contributed to the inference that research conducted in these countries has different approaches. It was also noted that the United States and France are the countries that have the most work in collaboration with other countries. This characteristic indicates that such countries should have international cooperation agreements that facilitate the development of collaborative research.

The collaborative network between institutions, in a complementary way, highlighted that interinstitutional collaboration does not correspond to a widespread alternative among researchers in the area. This aspect was justified by the fact that no institution leads the research-a feature that decentralizes studies and minimizes the possibility of exchange of experiences. The collaboration network between authors, in turn, highlighted that $78.76 \%$ of the works have two or more authors. Such performance reinforced the tendency to publish co-authored studies.

Finally, the impact indicators showed that only two authors of the most cited papers are among the most productive, which suggests that the most productive authors are not necessarily the most cited. In addition, it was highlighted that the most cited papers are distributed in journals specialized in areas, such as Information Systems Science, Production and Operations Management, and Business. This characteristic, in turn, reinforces the interdisciplinary character of competence-based management.

\section{Conclusions}

The main contribution of this paper is the use of bibliometric tools in the competence-based management research context to produce the results, which highlights, among other things, the existing link between competence-based management and knowledge management. Such a link reinforces the connection that exists among the knowledge that people have and the necessary competences that must be complied with for an organization to achieve its goals. Besides this, the identification of bibliometric characteristics of works that address competence-based management can improve research in the field, and consequently, benefit organization and individuals with its results. This is justified, as it is considered that this identification can boost the development of research and contribute to increase the credibility of these studies. Finally, it is possible to notice that papers about competence-based management can be developed in a more assertive way, considering the current state of research in this area. Furthermore, future studies can explore the research topics of the papers that compose the corpus created for this study in more depth. To this, would be interesting to do a systematic review to deeply identify the main approaches, results, and contributions of the studies that address this topic. This way, it would be possible to determine the issues that are getting more attention in this area, and any gaps in the research about competence-based management.

Author Contributions: Conceptualization, V.V.M.S. and G.R.A.; methodology, V.V.M.S., G.R.A., and S.E.C.; software, V.V.M.S., and G.R.A.; validation, S.E.C., and J.L.D.R.; formal analysis, V.V.M.S.; investigation, V.V.M.S.; data curation, V.V.M.S.; writing—original draft preparation, V.V.M.S.; writing—review and editing, G.R.A., S.E.C., and J.L.D.R.; supervision, S.E.C., and J.L.D.R.

Funding: This research received no external funding.

Conflicts of Interest: The authors declare no conflict of interest.

\section{References}

1. Hamel, G.; Prahalad, C.K. Competing for the Future; Harvard Business School Press: Cambridge, MA, USA, 1996; ISBN 978-0875847160.

2. Kaplan, R.S.; Norton, D.P. The Balanced Scorecard: Translating Strategy into Action; Harvard Business Review Press: Boston, USA, 1996; ISBN 9780875846514.

3. Boyett, I.; Currie, G. The failure of competence-based management education in the public sector-A problem of generic transfer or implementation? Pers. Rev. 2001, 30, 42-60. [CrossRef]

4. Urbizagastegui, R. Crescimento da literatura e dos autores sobre a Lei de Lotka. Ciência da Inf. 2009, 38, 111-129. [CrossRef] 
5. Borgman, C.L.; Furner, J. Scholarly communication and bibliometrics. Annu. Rev. Inf. Sci. Technol. 2005, 36, 2-72. [CrossRef]

6. Nerur, S.P.; Rasheed, A.A.; Natarajan, V. The intellectual structure of the strategic management field: An author co-citation analysis. Strat. Manag. J. 2008, 29, 319-336. [CrossRef]

7. Prévot, F.; Branchet, B.; Boissin, J.-P.; Castagnos, J.-C.; Guieu, G. The intellectual structure of the competence-based management field: A bibliometric analysis. In Research in Competence-Based Management; Sanchez, R., Heene, A., Zimmermann, T.E., Eds.; Emerald Group Publishing Limited: Bingley, UK, 2010; pp. 231-258.

8. Archambault, É.; Campbell, D.; Gingras, Y.; Larivière, V. Comparing bibliometric statistics obtained from the Web of Science and Scopus. J. Am. Soc. Inf. Sci. Technol. 2009, 60, 1320-1326. [CrossRef]

9. Abrizah, A.; Zainab, A.N.; Kiran, K.; Raj, R.G. LIS journals scientific impact and subject categorization: A comparison between Web of Science and Scopus. Scientometrics 2013, 94, 721-740. [CrossRef]

10. Bainbridge, H. Devolving people management to the line. Pers. Rev. 2015, 44, 847-865. [CrossRef]

11. Guillaume, R.; Houé, R.; Grabot, B. Robust competence assessment for job assignment. Eur. J. Oper. Res. 2014, 238, 630-644. [CrossRef]

12. van der Meer, F.M.; Toonen, T.A.J. Competency management and civil service professionalism in Dutch central government. Public Adm. 2005, 83, 839-852. [CrossRef]

13. Vakola, M.; Eric Soderquist, K.; Prastacos, G.P. Competency management in support of organisational change. Int. J. Manpow. 2007, 28, 260-275. [CrossRef]

14. Belkadi, F.; Bonjour, E.; Dulmet, M. Competency characterisation by means of work situation modelling. Comput. Ind. 2007, 58, 164-178. [CrossRef]

15. Palacios-Marqués, D.; Peris-Ortiz, M.; Merigó, J.M. The effect of knowledge transfer on firm performance. Manag. Decis. 2013, 51, 973-985. [CrossRef]

16. Hayton, J.C.; Kelley, D.J. A competency-based framework for promoting corporate entrepreneurship. Hum. Resour. Manag. 2006, 45, 407-427. [CrossRef]

17. Özçelik, G.; Ferman, M. Competency approach to human resources management: Outcomes and contributions in a Turkish Cultural Context. Hum. Resour. Dev. Rev. 2006, 5, 72-91. [CrossRef]

18. Capaldo, G.; Iandoli, L.; Zollo, G. A situationalist perspective to competency management. Hum. Resour. Manag. 2006, 45, 429-448. [CrossRef]

19. Leme Fleury, M.T.; Correa Fleury, A.C. In search of competence: Aligning strategy and competences in the telecommunications industry. Int. J. Hum. Resour. Manag. 2005, 16, 1640-1655. [CrossRef]

20. Colomo-Palacios, R.; Casado-Lumbreras, C.; Soto-Acosta, P.; García-Peñalvo, F.J.; Tovar-Caro, E. Competence gaps in software personnel: A multi-organizational study. Comput. Hum. Behav. 2013, 29, 456-461. [CrossRef]

21. Sanchez, R. Understanding competence-based management. J. Bus. Res. 2004, 57, 518-532. [CrossRef]

22. Berio, G.; Harzallah, M. Towards an integrating architecture for competence management. Comput. Ind. 2007, 58, 199-209. [CrossRef]

23. Flöck, C.; Mekhilef, M. Knowledge management in design: A multidisciplinary survey. In Proceedings of the 16th International Conference on Engineering Design, Paris, France, 28-31 August 2007.

24. Spinak, E. Indicadores cienciometricos. Ciência Da Inf. 1998, 27, 141-148. [CrossRef]

25. García-Lillo, F.; Claver-Cortés, E.; Marco-Lajara, B.; Úbeda-García, M. Identifying the 'knowledge base' or 'intellectual structure' of research on international business, 2000-2015: A citation/co-citation analysis of JIBS. Int. Bus. Rev. 2019, 28, 713-726. [CrossRef]

26. Hjørland, B. Domain analysis in information science. J. Doc. 2002, 58, 422-462. [CrossRef]

27. van Raan, A.F.J. Advanced bibliometric methods as quantitative core of peer review based evaluation and foresight exercises. Scientometrics 1996, 36, 397-420. [CrossRef]

28. García-Lillo, F.; Claver-Cortés, E.; Úbeda-García, M.; Marco-Lajara, B.; Zaragoza-Sáez, P.C. Mapping the "intellectual structure" of research on human resources in the "tourism and hospitality management scientific domain". Int. J. Contemp. Hospitality Manag. 2018, 30, 1741-1768. [CrossRef]

29. Köseoğlu, M.A.; Yildiz, M.; Okumus, F.; Barca, M. The intellectual structure of coopetition: Past, present and future. J. Strategy Manag. 2019, 12, 2-29. [CrossRef]

30. van Eck, N.J.; Waltman, L. Software survey: VOSviewer, a computer program for bibliometric mapping. Scientometrics 2010, 84, 523-538. [CrossRef] [PubMed]

31. Okubo, Y. Bibliometric Indicators and Analysis of Research Systems: Methods and Examples; OCDE: Paris, France, 1997. 
32. Fernandez-Alles, M.; Ramos-Rodríguez, A. Intellectual structure of human resources management research: A bibliometric analysis of the journal Human Resource Management, 1985-2005. J. Am. Soc. Inf. Sci. Technol. 2009, 60, 161-175. [CrossRef]

33. Torres-Salinas, D.; Lopez-Cózar, E.D.; Jiménez-Contreras, E. Ranking of departments and researchers within a university using two different databases: Web of science versus scopus. Scientometrics 2009, 80, 761-774. [CrossRef]

34. Meho, L.I.; Yang, K. Impact of data sources on citation counts and rankings of LIS faculty: Web of science versus scopus and google scholar. J. Am. Soc. Inf. Sci. Technol. 2007, 58, 2105-2125. [CrossRef]

35. Huang, Y.; Schuehle, J.; Porter, A.L.; Youtie, J. A systematic method to create search strategies for emerging technologies based on the Web of Science: Illustrated for 'Big Data'. Scientometrics 2015, 105, 2005-2022. [CrossRef]

36. Michels, C.; Fu, J.Y. Systematic analysis of coverage and usage of conference proceedings in web of science. Scientometrics 2014, 100, 307-327. [CrossRef]

37. Hofer, K.M.; Smejkal, A.E.; Bilgin, F.Z.; Wuehrer, G.A. Conference proceedings as a matter of bibliometric studies: The Academy of International Business 2006-2008. Scientometrics 2010, 84, 845-862. [CrossRef]

38. Bartol, T.; Budimir, G.; Dekleva-Smrekar, D.; Pusnik, M.; Juznic, P. Assessment of research fields in Scopus and Web of Science in the view of national research evaluation in Slovenia. Scientometrics 2014, 98, 1491-1504. [CrossRef]

39. Cobo, M.J.; López-Herrera, A.G.; Herrera-Viedma, E.; Herrera, F. Science mapping software tools: Review, analysis, and cooperative study among tools. J. Am. Soc. Inf. Sci. Technol. 2011, 62, 1382-1402. [CrossRef]

40. Meho, L.I.; Sugimoto, C.R. Assessing the scholarly impact of information studies: A tale of two citation databases-Scopus and Web of Science. J. Am. Soc. Inf. Sci. Technol. 2009, 60, 2499-2508. [CrossRef]

41. Scott, J. Social Network Analysis, 4th ed.; Sage Publications Ltd.: London, UK, 2017; ISBN 9781473952119.

42. Glänzel, W.; Schlemmer, B.; Schubert, A.; Thijs, B. Proceedings literature as additional data source for bibliometric analysis. Scientometrics 2006, 68, 457-473. [CrossRef]

43. Albanese, R. Competency-based management education. J. Manag. Dev. 1989, 8, 66-76. [CrossRef]

44. Moghabghab, R.; Tong, A.; Hallaran, A.; Anderson, J. The Difference Between Competency and Competence: A Regulatory Perspective. J. Nurs. Regul. 2018, 9, 54-59. [CrossRef]

45. Glänzel, W.; Schubert, A. Analysing scientific networks through co-authorship. In Handbook of Quantitative Science and Technology Research; Moed, H.F., Glänzel, W., Schmoch, U., Eds.; Springer: Dordrecht, The Netherlands, 2005; pp. 257-276. ISBN 1-4020-2702-8.

46. Sein, M.K.; Henfridsson, O.; Purao, S.; Rossi, M.; Lindgren, R. Action Design Research. MIS Q. 2011, 35, 37-56. [CrossRef]

47. McDermott, C.M.; O'Connor, G.C. Managing radical innovation: An overview of emergent strategy issues. J. Prod. Innov. Manag. 2002, 19, 424-438. [CrossRef]

48. Lindgren, R.; Henfridsson, O.; Schultze, U. Design principles for competence management systems: A synthesis of an action research study. MIS Q. 2004, 28, 435-472. [CrossRef]

49. Gottschalk, P.; Solli-sæther, H. Critical success factors from IT outsourcing theories: An empirical study. Ind. Manag. Data Syst. 2005, 105, 685-702. [CrossRef]

50. Torkkeli, M.; Tuominen, M. The contribution of technology selection to core competencies. Int. J. Prod. Econ. 2002, 77, 271-284. [CrossRef]

51. Harzallah, M.; Vernadat, F. IT-based competency modeling and management: From theory to practice in enterprise engineering and operations. Comput. Ind. 2002, 48, 157-179. [CrossRef]

52. Chau, T.; Maurer, F.; Melnik, G. Knowledge Sharing: Agile Methods vs. Tayloristic Methods. In Proceedings of the IEEE International Workshops on Enabling Technologies: Infrastructure for Collaborative Enterprises (WETICE'03), Linz, Austria, 11 June 2003; pp. 302-307.

53. Ermilova, E.; Afsarmanesh, H. Modeling and management of profiles and competencies in VBEs. J. Intell. Manuf. 2007, 18, 561-586. [CrossRef]

(C) 2019 by the authors. Licensee MDPI, Basel, Switzerland. This article is an open access article distributed under the terms and conditions of the Creative Commons Attribution (CC BY) license (http://creativecommons.org/licenses/by/4.0/). 